International Journal of Innovative Science

\title{
and Research Technology
}

ISSN (Online) :- 2456-2165

Volume 4, Issue 11, November - 2019

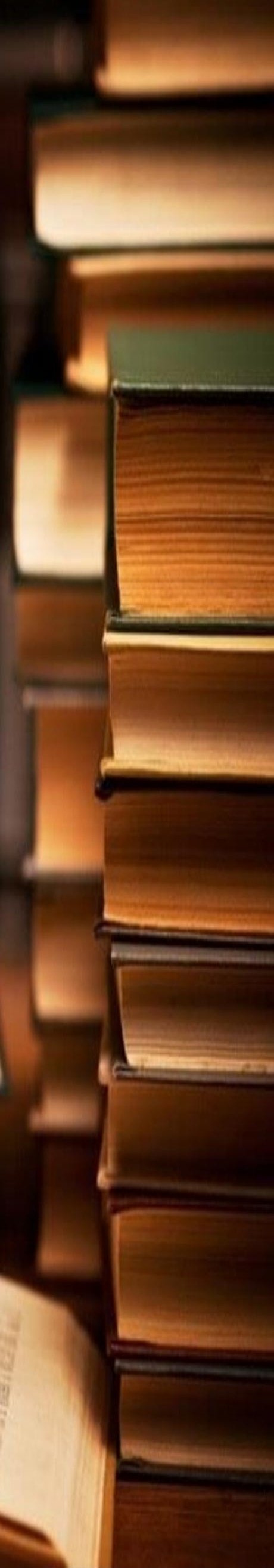




\section{EDITORIAL BOARD}

Manish Gupta (IJISRTREW100)

| Assistant professor | ECE Dept.| VIT jaipur | Rajasthan | India

HemantPurohit (IJISRTREW77)

| Professor \& HOD ECE dept.| JIET | Jodhpur | Rajasthan | India

Jai Prakash Mishra (IJISRTREW13)

| Assistant Professor| ECE Dept.| VIT Jaipur | Rajasthan |India

Harsh Gupta (IJISRTREW02)

| Micro Electronics Dept. | Manipal University | Jaipur | Rajasthan | India

DiwakarGautam (IJISRTREW05)

| Assistant professor | ECE Dept. | Sharda University

TarunBadiwal (IJISRTREW09)

| Assistant Professor | Electrical Dept. | Jaggannath University | Jaipur | Rajasthan | India

Virendra Swami (IJISRTREW105)

| Assistant Professor | ECE Dept. | MaharshiArvind college| Jaipur |Rajasthan | India

Nishant Chauhan (IJISRTREW79)

| Assistant Professor | Electrical Dept. | MahershiArvind College| Jaipur |

Rajasthan | India

Prince Ja.cob (IJISRTREW91)

| Assistant Professor | Electrical Dept. | MahershiArvind College| Jaipur | Rajasthan | India

Dr.S.SairaBanu (IJISRTREW10)

| Associate Professor | ECE Dept. | Karpagam University| Coimbatore | Tamil Nadu | India

BalajiVelusamy (IJISRTREW500)

| Associate Professor | Info Institute of Engineering| Coimbatore | Tamil Nadu | India

Lalit Mohan Nainwal (IJISRTREW501)

|School of Pharmaceutical Sciences and Research| JamiaHamdard| Delhi | India

BaisNiravKishorkumar (IJISRTREW502)

|Assistant Professor|Ganpat University-Institute of Technology| Ahmedabad| Gujarat | India

Raj Kumar Gupta (IJISRTREW503)

|Assistant Professor|Amity University| Jaipur| Rajasthan | India

Dr. Neeta Saxena (IJISRTREW504)

|Assistant Professor|Amity University| Gwalior| Madhya Pradesh | India

Dr.Nageswara Rao Moparthi(IJISRTREW505)

|Associate Professor| Velgapudi Ramakrishna Siddhartha Engineering College|

Vijayawada | Andhra Pradesh | India

R. Narendran(IJISRTREW506)

|Faculty of Marine Sciences| Annamalai University| Parangipettai | Tamil Nadu | India

Mahadeva.M (IJISRTREW507)

|Assistant Professor| Shri Pillappa College of Engineering | Bangalore| Karnataka| India 


\section{Indexing}

\section{SJIF Impact Factor : 5.15}

\section{(-) issuv \\ Google}

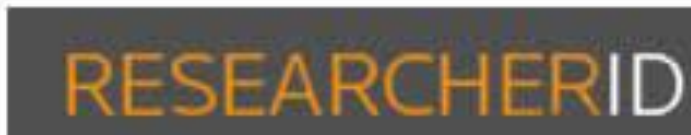

\section{THOMSON REUTERS}

INDEX COPERNICUS

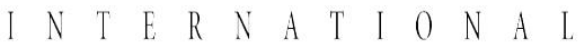

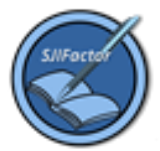

TOGETHER WE REACH THE GOAL.
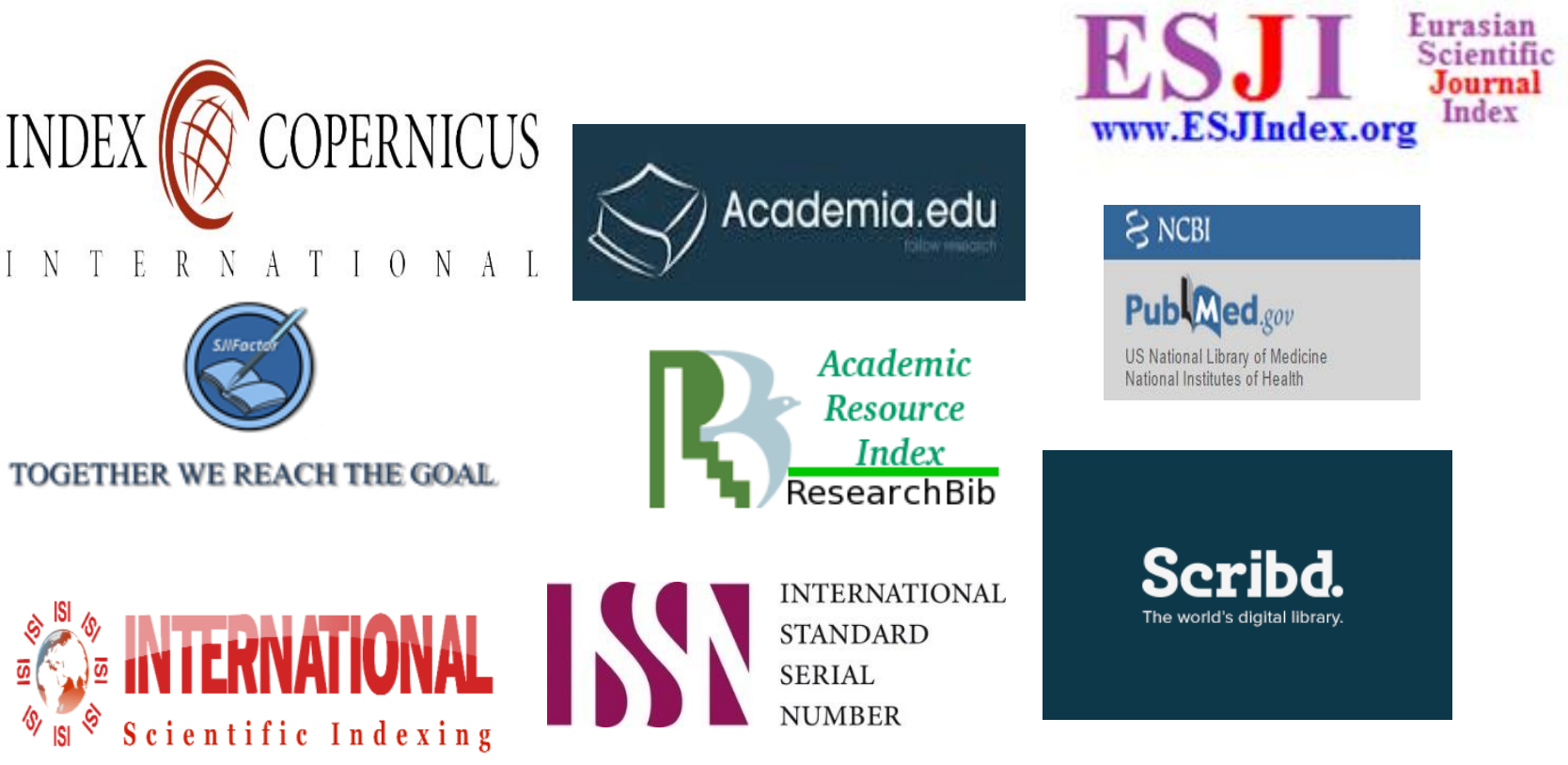

Seribd.
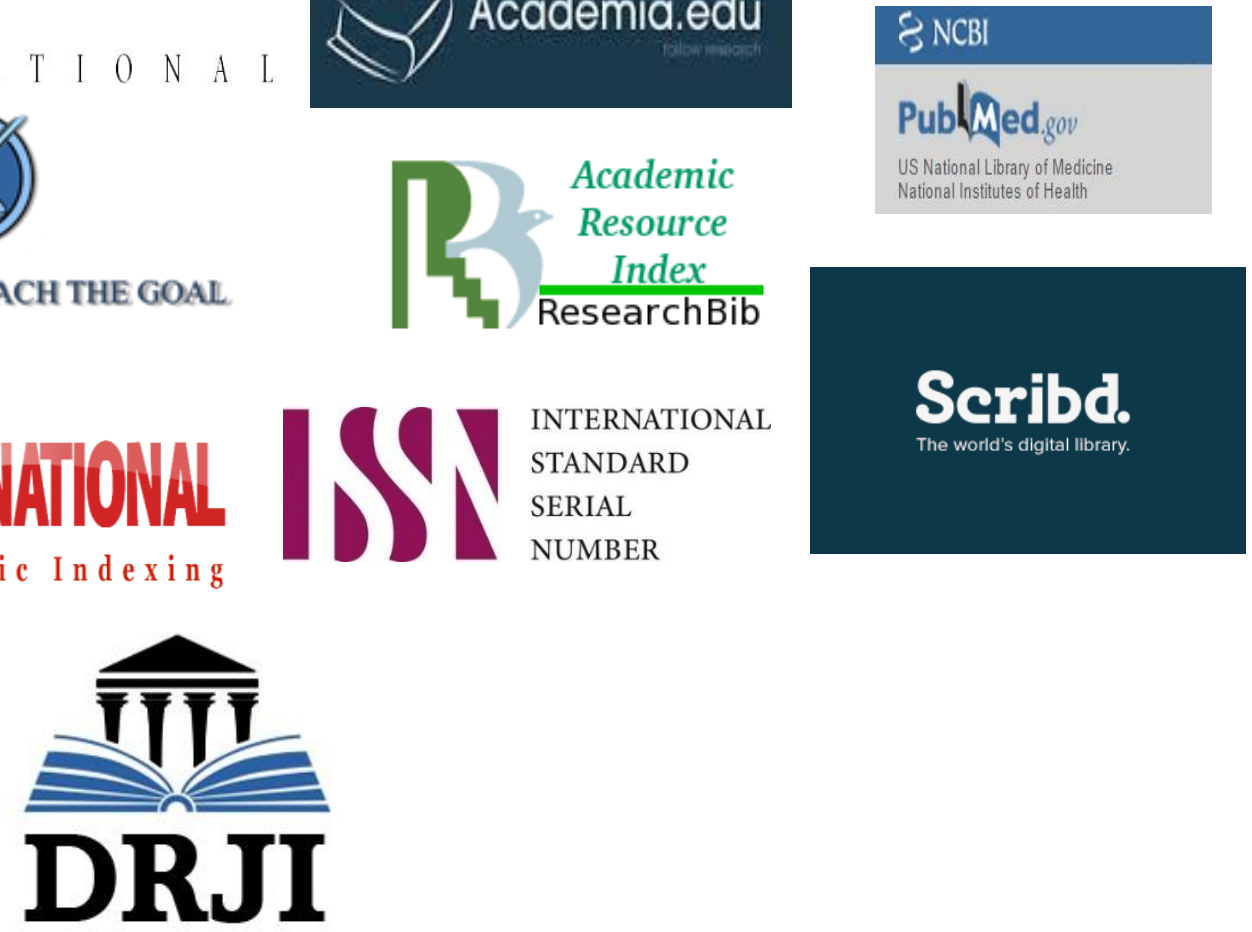


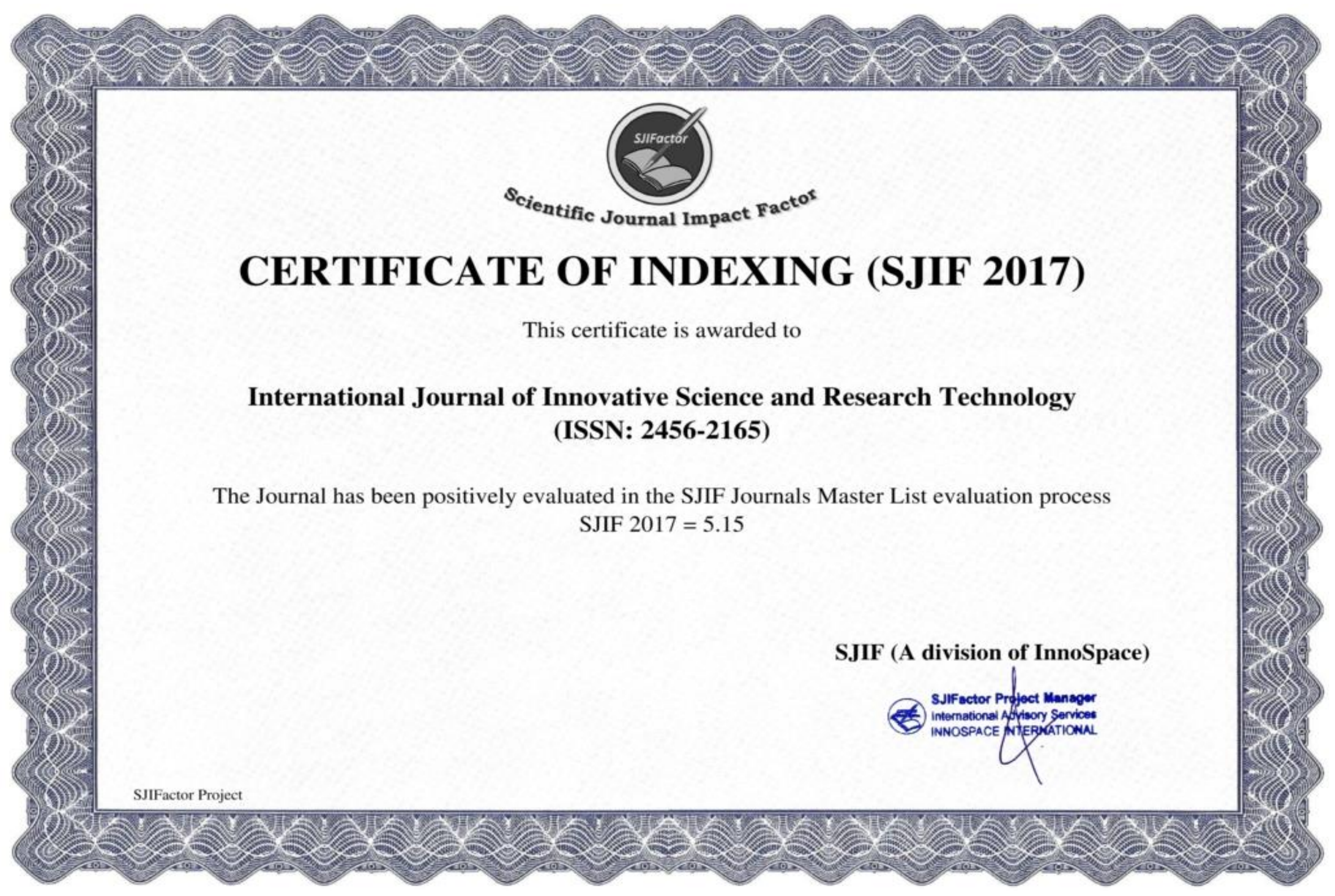




\section{TABLE OF CONTENT \\ Volume 4 - 2019, Issue 11 - November}

1. Influence of Social Media Marketing Communications among Young Consumers Author Name : Jinang, Noralyn; Balitao, Kenji P.; Mendoza, Hannah Sophia A.; Nartea, Mecmack; Medina, Estelita E.; Munsayac, Jennifer D.

2. Innovative Futuristic Approach for Sustainable Sugar Industry

Author Name : Narendra Mohan \& Anushka Agarwal

3. Soft Skills and Other Influences in Teaching Related To Work Experience at College of Health Technology, Pankshin, Plateau State, Nigeria

Author Name : Habila Dang Pam, Stephen M. Abang, Lilian Dang Pam

4. The Nexus between Immigration in Southern Africa and International Conventions, Regional Protocols and Domestic Legislations for Management of Migration Author Name : Prosper Ng'andu

5. Adaptive Nonlinearity Estimation of Time Interleaved Analog-to-Digital Converter using Recursive Least Square Technique

Author Name : Sedki Younis, Abdulrahman Kh. Alhafid, Omar Mowaffak Alsaydia

6. The Determinant Effect of Theory of Planned Behavior and Tax Knowledge on Taxpayer Compliance

Author Name : Muzakkir, Aini Indrijawati, and Syamsuddin

7. Analysis Problem and Improvement of Appearance Aesthetics Product Model HC C5 / XT with Method of Plan-Do-Check-Action (PDCA) In Pt. XXXX

Author Name : Sugeng Santoso, Dhani Mayrifka

8. A Study on Socio-Demographic Profile and Injury Pattern of Patients with Head Injury in Victims of Road Traffic Accident in a Tertiary Care Center of South India

Author Name : Vaanathi Ra, Dr. Shruthi P

9. Performance Comparison between Conventional and Sharia Mutual Funds in Indonesia

Author Name : Nanang, Bambang Santoso Marsoem

10. The Effect of Human Resource Competencies, Commitment, and Society Participation on the Accountability of Village Financial Management with Makassar's Bugis Culture as a Moderating Variable

Author Name : Irmawati, Nirwana, R.A. Damayanti

11. Sociodemographic Profile and Pattern of Injuries of Poly Trauma Cases of Road Traffic Accidents in a Tertiary Care Center

Author Name : Vaishali Ashok, Dr. Shruthi P

12. The Moderation Effect of Spirituality in Relationship of Competence and Internal Control System on the Quality of Local Government Financial Statement

Author Name : Dwi Nurul Ikhwani, Haliah, Nirwana 
13. The Effect of Individual Factors and Technical Factors on the Quality of Financial Statements with the Leadership Style as a Moderating Variable Author Name : Nurul Huda Yus'an, Aini Indrijawati, Darwis Said

14. Effectiveness of Video Assisted Teaching Module on Knowledge and Attitude Regarding Health Effects of Internet Addiction Disorders among Adolescents Author Name : Santosh B Sajjan, Dr. Deelip S. Natekar, Moulasab.N, Shivaraj.M, Shobha.J, Shambhavi.K, Shridhar.P, Sunil.N, Subhas.B, Rohit K

15. Comparison of Microbiological Profile of Nosocomial Organisms in ICU and Wards for a Period of 3 Months

Author Name : Daniel Paul, Dr. Tasneem

16. Socio-Economic Condition and Medical Facilities of Garments Workers of Gazipur District, Bangladesh Author Name : Md. Rakibul Islam

17. Nepal-India Open Border: Use and Misuse Author Name : Saroj K. Timalsina

18. Passenger Performance at Ngurah Rai The Airport Indonesia Author Name : Ni Made Satya Utami, Nilna Muna, Made Setini, Bayu Imanuddin

19. From Communication to Corporate Communication - A New Conceptual Framework Embodied in Strategic Planning Author Name : Ana Sofia Marcelo, Ana Matias, Luis Cardoso

20. An Insight into the Journey of Silver Nano Particles Infused to PMMA Resin Author Name : Dr. Geetha K. R. M. D. S., Dr R. Prabhu M.D.S., Gobika .R, Harini.T, Shalini Shiva Sankar

21. Knowledge about Periodontal Problems among Female Patients Visiting the Department of Periodontics at the Thai Moogambigai Dental College and Hospital in Chennai

Author Name : Gayathri. M, Gobika. R, Rajkumar. R, Dr. Uma Sudhakar M.D.S PhD

22. Foreign Bodies of the Ear and Nose- A Novel Technique of Removal

Author Name : Dr Oliyath Ali, Dr Ishrit Yasin, Dr Amina Khatoon, Dr Stanzin Angmo, Dr Shazia Naaz, Dr Asif Hussain, Dr Abbas Ali, Dr Kacho Akbar Khan

23. Dose Escalation using Kaplan-Meier (Product-Limit) Model Author Name : Mary Chriselda A, Maria Roopa Thomas

24. Version Control using Layered Architecture and Design Patterns for GITHUB Author Name : Ayisha Siddiqua L, Dr.A.Gayathri

25. Plant Performance on Several Maize-Soybean Intercropping Patterns Inoculated With Arbuscular Mycorrhizal Fungi and Organic Matter in the Suboptimal Land of North Lombok

Author Name : Lalu Muhammad Ariandi Sahiran, Wahyu Astiko, and Mulyati

26. Proliferating Practicum in Present Evaluation System

Author Name : Vaishnavi. S. J. 
27. Determinants of Using Go-Pay and its Impact on Net Benefits Author Name : Gede Leo Nadi Danuarta, Gede Sri Darma

28. The Restoration of Iban 'IUR' Motive into Iban Pop Song Author Name : Willy Alfred Ting, Yoesbar Djaelani

29. Oral Hygiene Awareness and Practice among Patients Visiting the Department of Periodontics at the Thai Moogambigai Dental College and Hospital in Chennai Author Name : Shalini.S, Amreen ara, Saranya.R, Dr. Uma Sudhakar

30. Awareness of Periodontal Treatment Modalities among Interns Author Name : V. Jenifer Charu Prabhu, S. Kalaivani, D. M. Jenisha, Dr. Uma Sudhakar

31. Impact of Macroeconomic Policy on the Development of the Construction Market. Study of the Example of Bulgaria Author Name : Aneta Marichova

32. ICT Impact on Quality and Excellence in Library Functions, Collections, Services and its Impression on NAAC and NBA Policy in Higher Education

Author Name : Charushila Rajan Gaikwad

33. Biological Hotspot of Ichthyoplankton in the Estuarine Environment Timbulsoko Village, Demak

Author Name : Hanityo Nugroho, Sutrisno Anggoro and Ita Widowati

34. An Improved Methodology for Cost Estimation of Defence Research and Development Projects in India with Special Emphasis on Risk Analysis

Author Name : Navya Bansal, Nitin Kumar Yadav, Manish Bhatnagar

35. Feasibility Study of Hospital with a Capital Budgeting Approach

Author Name : Shabrina Amalia, Harryanto, Syamsuddin

36. Effect of Organizational Justice on Organizational Citizenship Behaviour at Polytechnic of Shipping Barombong Makassar City

Author Name : Ilham Ashari, Rahmat, Atta Irene Allorante, Badu Ahmad

37. A Study of Awareness of POCSO Act 2012 amongst faculty of Private Medical College at Chennai

Author Name : Yasvanth. S, Dr. Shruthi. P

38. Flame Photometric Determination of Lithium in Red Kidney Beans, Lentils and Teen Talav Water

Author Name : Pooja Vinod Jagasia, Vasant D.Barhate

39. A Framework for Telemedicine Care: A Case of Nandi County - Kenya

Author Name : Sammy Amdany, John O Olouch, James O Abila

40. Planning and Scheduling of Low Income Housing Scheme Project by Line of Balancing Method

Author Name : Amey Satish Darange, Mahesh B.Sonawane 
41. The Effect of Educational Curriculum and Training of Leadership Level IV, Widyaiswara Competency and Infrastructure Facilities of Performance Education and Training Results Graduates of Education and Leadership Training Level IV in the Human Resource Development Agency West Java Province

Author Name : Suryana

42. Quality Analysis of Service, Trust, and Perception of Information Technology on Satisfaction and Loyalty of Internet Banking Customers Using Government Banks in Makassar City

Author Name : Novita Rosanti, Syahnur Said, Bahar Sinring, Ramlawati

43. Assessment of Heavy Metal Composition and Cytogenotoxic Risk Potential of Dumpsite Soil and Water Collected from Kogi State University Students Halls of Residence

Author Name : Onoja, A.O.; Egbeja, T. I.; Kadiri, J. U.; Edogbanya, P. R. O.; Oguche, J. U.; Alaji, P. O.; Onifade, D. D.; Osagiede, D. O.; Ibrahim, H. G.

44. The Analysis of Nurse Compliance in Documenting of Nursing Care in Islamic Hospital Palembang

Author Name : Muhamad Andika Sasmita Saputra, Alkhusari

45. Carbonic Anhydrase QSAR Model as Templates for Biomarkers Discovery

Author Name : Lungu N. Claudiu

46. Comparison of Lignocaine AMD Normal Saline in the Management of PostTonsillectomy Pain

Author Name : Mruthula Hamsraj, Dr. Raadhika Shree

47. Edge Detection Techniques on Digital Images - A Review

Author Name : J. S. Owotogbe; T. S. Ibiyemi; B. A. Adu

48. Groove Design and Its Influence on Strength of SMAW Joint

Author Name : Mr Raghu; E. Srinath Reddy; B. Chennakeshavulu; Aman Kumar Singh; G. Abdul Kadir

49. Analysis of Brand Awareness, Brand Images, Halal Labels and Products towards Purchase Intention of Wardah Consumers

Author Name : Fariz Adlan; Dr.Sri Hartono

50. Some Geotechnical Properties of Soils Around Eziobodo, Imo State, Southeastern Nigeria

Author Name : Nwachukwu, P. C.; Popoola, J. O.; Uja, E. U.

51. Review on NLP Paraphrase Detection Approaches

Author Name : Swati Meshram

52. The Microwave Assisted Rapid and Efficient Synthesis of Azlactones

Author Name : Amit P.Tayade; Ramkrushna P. Pawar; Rajiv V. Khobare; Chandakant B.Mane; Nitin P. Tayde

53. One Pot and Three Component Synthesis of 4-aryl-3-Methylisoxazole-5(4H)-One Derivative in the Presence of Sodium Hypophosphite

Author Name : Amit P.Tayade, Ramkrushna P. Pawar, Rajiv V. Khobare, Chandakant B.Mane, Nitin P. Tayde 
54. Improve Kinetics of Hydrogen Storage in Sodium Alante Codoped with TiO2, TiF4, TiAl and TiCl3

Author Name : Dr. Jameel khan

55. The Impact of FDI Inflows on Economic Growth: An Empirical Study for the Senegal

Author Name : Moussouba Diedhiou

56. A Descriptive Study to Assess the Stressors, the Level of Stress and Coping Mechanisms of Married Student in Selected Nursing College in Namakkal District, Tamilnadu

Author Name : Sheelavathi

57. Facilitating Learning and Academic Performance of Students in TLE under K to 12 Curriculums

Author Name : Thelma L Alsong, Ludy A. Alsong

58. Bacterial Degradation of Lignin: A Prospective for Lignocellulosic Biofuels Author Name : Ajith S

59. Formulation and Evaluation of Herbal Lipstick from Broccoli Flower Extract and Analytical Bioactive Characterization and Quantification

Author Name : Sunayana. Singu, Revan Siddappa. Malgi, Uttam Prasad Panigrahy, Abbulu. Konde

60. The Laguito Water Body in Cartagena and its Sedimentation Legal Problem against the Increase of the Sea Level for Climate Change

Author Name : Elizabeth Ramirez Llerena, Hebert Rico Royero, Nilson Figueroa Atencia, Lourdes Villadiego Coneo, Ana Temis Herrera Barragán, Maria Alejandra Benitez Hurtado

61. Knowledge and Awareness among Dental Students about Choice of Complete Denture Occlusion in Edentulous Patient

Author Name : Dr. Geetha K. R. M. D. S., Dhivyaa Deve.K, Dhanvarshini. M. R, Dr.R.Prabhu M.D.S, Aarthi.P.S

62. The Study of Brand Support from the Perspective of Crisis management

Author Name : Kao-Shan Chen, Shih-Tse Lin, Mei-Yun Huang

63. Discipline Effect, Motivation and Work Environment to Employee Performance in PT. Telecommunication of Indonesia TBK, Witel Bogor

Author Name : Eva Lestari Bangun; Dr. Kasmir SE

64. Factor Analysis - Factors Affecting Performance Organizatio (CASE STUDY Maybrat Regency)

Author Name : Cliff Sangkek, Se

65. Dental Implant Awareness among Patients in Our Institution in Chennai-CrossSectional Survey

Author Name : Dr.Geetha, Dr.Prabhu, Poornika Anandan, Praveen Kumar 
66. A Study to Evaluate the Effectiveness of Planned Teaching Programme on Knowledge Regarding Prevention of Home Accidents among Mothers of Under-five Children in Community Area Bagalkot

Author Name : Dr. Deelip S. Natekar, Sureshgouda S Patil, Chandrashekhar, Kavita Chalawadi, Darshini Gulannavar, Daneshwari Belagali, Babu Asangi, Bhimappa

67. Community-Based Eco Activity: An Out-of-School Youth Environment Education Program

Author Name : Ruel T. Bonganciso

68. Artificial Intelligence in Transport and Logistics

Author Name : Asya Tsonkova 


\title{
The Analysis of Nurse Compliance in Documenting of Nursing Care in Islamic Hospital Palembang
}

\author{
Muhamad Andika Sasmita Saputra ${ }^{1}$, Alkhusari $^{2}$ \\ Department of Nursing Science, Faculty of Midwifery and Nursing ${ }^{1,2}$ \\ Kader Bangsa University, Palembang
}

\begin{abstract}
Nurses' obedience in implementing the nursing care documentation is still a phenomenon that occurs in several hospitals in Indonesia. This study attempts to analyze the nurses' obedience in documenting the nursing care. This quantitative study used a correlation method with a cross-sectional approach, samples from 63 implementing nurses and 63 of the nursing care documentation obtained by using proportionate random sampling technique. The results showed the highest proportion were age $<35$ years $(\mathbf{7 3 . 0 2 \%})$, women $(\mathbf{9 3 . 6 5 \%})$ with vocational education (95.24\%), Length of employment $\geq 2$ years $(96.83 \%)$ with permanent employee status $(95.24 \%)$ and most of the nurse disobedience in documenting the nursing care $(\mathbf{9 8 . 4 1 \%}$ ). There was no correlation among Age (p-value $=0.270$ ), Gender, Education, Length of employment, Staffing Status $(p-v a l u e=1.000)$. The researcher suggested that the Palembang Islamic Hospital to conduct a review of the nursing care format form and SPO the nursing care documentation including the SPO implementation, then conduct periodic internal audits, provide training or include nurses in training in filling the nursing care documentation used in the Palembang Islamic Hospital that also needs to be done, as well as optimizing the reward and punishment system for nurses related to the implementation of the nursing care documentation.
\end{abstract}

Keywords:- Obedience, Documentation, Nursing Care.

\section{INTRODUCTION}

The nursing care documentation is still a problem in hospitals, even though documentation is one of the vital documents. Each implementation is not far from the five items of the nursing process which include assessment, diagnosis, intervention, implementation, and evaluation [1, 2]. The results of the research in the last few years have reported that there are still many numbers of nurse disobedient in documenting the nursing care such as research that conducted at The ICU-ICCU Room Gambiran Regional Public Hospital (RSUD. Gambiran) of Kediri, East Java 57.9\%, in Ambarawa Inpatient Room of Regional Public Hospital [3-5].

Disobedient of nurses in documenting the nursing care can lead to malpractice and duplication of nursing actions performed. According to the concept of the nursing care, one of the objectives of documentation is as a communication tool, the mechanism of accountability and as an audit of nursing services [6-8]. The more nurses who do not obey in documenting the nursing care, the higher the risk of errors in the provision of the nursing care, the less evidence of responsibility and accountability for nurses. To avoid this, the role of a nursing manager in managing documentation of the nursing process is very important, especially related to nurses' disobedient.

Disobedient of nurses is the key to failure in documenting the nursing care. Disobedient is an entity crime, whether intentionally or not someone is against a plan or rule $[9,10]$. Various studies on nurse disobedient in documenting the nursing care have been carried out. The results of the study reported that there were four factors that hindered nurses' obedience in documenting the nursing care, namely: (1) the imbalance in the number of nurses with existing jobs, (2) the format was too long, (3) the nurse's motivation to document, and (4) knowledge poor nurse [11-13]. In addition to the results of the study, several performance theories explain the factors that influence nurse performance, including performance in documenting the nursing care.

Many performance theories are used in the field of nursing, one of which is the performance theory proposed by Gibson in 1987. According to Gibson's performance concept, three main variables influence a person's performance, namely: (1) individual variables, (2) organizational variables and (3) variables psychological. Individual variables include ability, skills, educational background, and nurse work experience in documenting the nursing care. While organizational variables include resources that support the implementation of documentation, the leadership of the head of the room in mentoring the implementation of documentation of the nursing care, rewards, work structures related to the process of documentation and design work. Psychological variables include perceptions, attitudes, personality, learning and nurse motivation in documenting the nursing care [14].

Based on the descriptions above, the researcher traced the initial data using the method of observation and interview at the research site. The interview with the head of the inpatient installation of the Palembang Islamic Hospital in the nursing care documentation used as a type of checklist in the assessment section, nursing diagnoses. In the evaluation/progress note the patient used the SOAP model (Subjective data, Objective data, Assessment, Planning). Since 2015, diagnoses and nursing interventions refer to the diagnosis of NANDA. The installation head also said that it was not yet known what percentage of nurses' obedience in documenting the nursing care was 
because the hospital had not made calculations based on the five aspects of the nursing care documentation process.

To find out more, the researchers observed ten patients' status in several rooms, with results: $12.5 \%$ assessment, $43.4 \%$ diagnosis, $53.4 \%$ intervention, $42.5 \%$ implementation, $40 \%$ evaluation, and completeness $26 \%$ the nursing care documents that were not filled by nurses. There were several aspects of the nursing care documentation that were not filled and not attached or included in medical record documents, mostly on diagnostic forms and treatment interventions. There were still the nurses who wrote non-nursing activities on the implementation form such as changing linen and shift operands but not including the activities listed on the intervention form, nurses also did not write names and include signatures or initials. Through phenomenon that occurred in the field and the theory of individual variables proposed by Gibson made researchers tried to determine the correlation of respondents' characteristics (age, gender, education, length of work, and employment status) with nurses' obedience in documenting the nursing care.

\section{METHODS}

\section{A. Study Design}

This quantitative study used a correlation method with a cross-sectional approach so that the variables can be measured in a one-time unit. The variables that were correlated was characteristic variables with nurse obedience in documenting the nursing care.

\section{B. Setting}

The study was conducted from June 2017 to May 2018 and data collection began on March to April 2018 in the Inpatient Room of Palembang Islamic Hospital.

\section{Sample}

The population in this study were all 75 nurses implementing the inpatient ward of the Palembang Islamic Hospital. To facilitate data retrieval, the researchers divided the number of nurses so that the number of samples was obtained as much as 63 implementing nurses and 63 the nursing care documents obtained by using the proportionate random sampling technique. Furthermore, the sample was divided based on the treatment room including 22 respondents in the internal medicine room, 8 respondents in the surgical room, 8 respondents in the pediatric room, 4 respondents in the perinatal room, VIP A 8 respondents room, VIP B 5 respondents and VIP C 8 respondents.

\begin{tabular}{|c|c|c|c|}
\hline No & Room Name & N & n \\
\hline 1 & Internal Medicine & 26 & $26 / 75 \times 63=22$ \\
\hline 2 & Pediatric & 9 & $9 / 75 \times 63=8$ \\
\hline 3 & Surgical & 10 & $10 / 75 \times 63=8$ \\
\hline 4 & Perinatal & 5 & $5 / 75 \times 63=4$ \\
\hline 5 & VIP - A & 9 & $9 / 75 \times 63=8$ \\
\hline 6 & VIP - B & 7 & $9 / 75 \times 63=5$ \\
\hline 7 & VIP -C & 9 & $9 / 75 \times 63=8$ \\
\hline Total & & 75 & 63 \\
\hline
\end{tabular}

Table 1:- Number of Implementing Nurse Samples in the Inpatient Room of the Palembang Islamic Hospital

- Inclusion Criteria: Nurses who document new patients, Willing to be respondents.

- Exclusion Criteria: Nurses who were on leave, Nurses who were doing study assignments, Implementing nurses in the ICU / ICCU Room.

The researcher first explained the aims and objectives of the research to the hospital, then asked for a list of names of the implementing nurses and the nurse's shift schedule at the head of the room. The names were then randomized by drawing 63 samples that had been determined based on the room, each name that appears will be determined as the research sample.

Characteristic data retrieval was conducted by researchers meeting respondents at the respondent's official schedule, researchers obtained data when the respondent was resting. The researcher introduces himself first and then explains the plan and purpose of the research to prospective respondents. Prospective respondents who agreed to participate in the study were welcome to sign an informed consent form.

Nurse obedience data was obtained by observing 63 pieces of the nursing care documents. The observed document was a new patient's the nursing care document that was signed or reads the name of the nurse who was the respondent when there were two, three or more documents with one nurse's name then only one was selected. Documents traced were available in the inpatient room and had received permission from the head of the room and not taken from the medical record section. Document observation was conducted on the third day after the patient enters. Documents for transfer patients from other rooms were not taken, because the patients transferring their the nursing care documentation were advanced, which were continued from the previous room nurse. This data retrieval process involves two assistants who had mastered nursing degrees and had experience in the field of documenting the nursing care. 


\section{Instrument}

Measurement of nurse obedience in documenting the nursing care taken by observation by using "Instrument A" from the book of "An Instrument for Evaluating the Application of The nursing care Standards at Hospitals" of Health Department of the Republic of Indonesia [15].

This was observation type of instrument with Guttman Scale to get a firm answer, if was conducted by a nurse then checked and wasn't conducted by the nurse was given a cross which include assessments with four items of observation, diagnosis with three items of observation, intervention by the six items of observation, the implementation of the four items of observation, evaluation two items of observation, and the completeness of the record documents with five items of observation so that a total of 24 items were observed by researchers.

Evaluation of this data was grouped first by room starting from the assessment, diagnosis, intervention, implementation, evaluation, and completeness of document records. Nursing documentation activities that had been carried out by nurses in this instrument were then given a value of 1 whereas if wasn't conducted by nurses the value was 0 , then the value was totalled, the outputs produced in the form of percentages that based on the calculation formula of Health Departement of the Republic of Indonesia :

\section{Percentage $=\frac{\text { Total }}{\text { Number of files } \times \text { Number of aspects assessed }}$ $\times 100 \%$}

If the sum was $<80 \%$, it will be categorized as disobedient, while $\geq 80$ categorized obedient. There was no development or modification of the instrument, nor was there a validity and reliability test because this instrument was the standards of the government and reference standards were used by Palembang Islamic Hospital.

\section{E. Data Analysis}

The observed the nursing care document was a new inpatient care document that was treated no more than three days by the nurse who was the respondent. This observation did not apply to transfer patient care documents from other inpatient rooms or referrals. The data collected was then categorized and then analyzed univariately. Nurses were said to be obedient if $\geq 80 \%$ of the nursing care documentation was filled or completed by nurses. The bivariate analysis used the chi-square test to determine the relationship between nurses' characteristics and nurses' obedience.

\section{F. Ethical Consideration}

This research had passed the ethical test stage and was declared feasible by the Research Ethics Commission of the Muhammad Hoesin Central General Hospital (RSUP. Muhammad Hoesin) and the Medical Faculty of the Sriwijaya University Palembang with a certificate number: 72/kepkrsmhfkunsri/2018.

The researcher applied the principle of giving freedom to the respondent to participate in the research after getting an explanation of the intent and purpose and benefits of the research. Respondents received an explanation of the purpose and benefits of the research and research procedures, then the respondent was given a consent sheet to become the respondent who had been prepared beforehand by the researcher. Respondents who were willing to participate in the study signed concentrated informed consent, but if the respondent refused, the researcher still respected his rights. Researchers maintain the confidentiality of all information obtained from respondents during the study. Respondents were given an understanding that the data provided did not adversely affect his career and work. All data obtained by researchers will be stored properly and used only for reporting this research.

\section{RESULTS}

After researching 63 nurses and 63 the nursing care documents, the following data were obtained :

\begin{tabular}{|c|c|c|c|}
\hline Characteristics & Category & $\mathbf{f}$ & $\%$ \\
\hline Age & $\begin{array}{l}<35 \text { Years } \\
\geq 35 \text { Years }\end{array}$ & $\begin{array}{l}46 \\
17\end{array}$ & $\begin{array}{l}73.02 \\
26.98\end{array}$ \\
\hline Gender & $\begin{array}{c}\text { Male } \\
\text { Female }\end{array}$ & $\begin{array}{c}4 \\
59 \\
\end{array}$ & $\begin{array}{c}6.35 \\
93.65 \\
\end{array}$ \\
\hline Education & $\begin{array}{c}\text { Vocational } \\
\text { Professional }\end{array}$ & $\begin{array}{c}60 \\
3\end{array}$ & $\begin{array}{c}95.24 \\
4.76\end{array}$ \\
\hline Length of Employment & $\begin{array}{l}<2 \text { Years } \\
\geq 2 \text { Years }\end{array}$ & $\begin{array}{c}2 \\
61\end{array}$ & $\begin{array}{c}3.17 \\
96.83\end{array}$ \\
\hline StaffingStatus & $\begin{array}{c}\text { Contract } \\
\text { Permanent }\end{array}$ & $\begin{array}{c}3 \\
60\end{array}$ & $\begin{array}{c}4.76 \\
95.24\end{array}$ \\
\hline Nurse Obedience in Documenting The Nursing Care & $\begin{array}{c}\text { Obedient } \\
\text { Disobedient }\end{array}$ & $\begin{array}{c}1 \\
62 \\
\end{array}$ & $\begin{array}{r}1.59 \\
98.41 \\
\end{array}$ \\
\hline
\end{tabular}

Table 2:- Frequency Distribution of Characteristics of Implementation Nurses at Palembang Islamic Hospital in 2018 ( $\mathrm{n}=63$ ) 
ISSN No:-2456-2165

Table 2 showed the characteristics of implementing nurses who were respondents in this study. The highest proportion of nurses aged <35 years $(73.02 \%)$, gender female $(93.65 \%)$, vocational education $(95.24 \%)$, Length of
Employment $\geq 2$ years (96.83\%), Permanent Staffing status (95.24\%). Table 1 also showed that out of 63 nurses only $1.59 \%$ of nurses who obediently that carry out documentation of the nursing care.

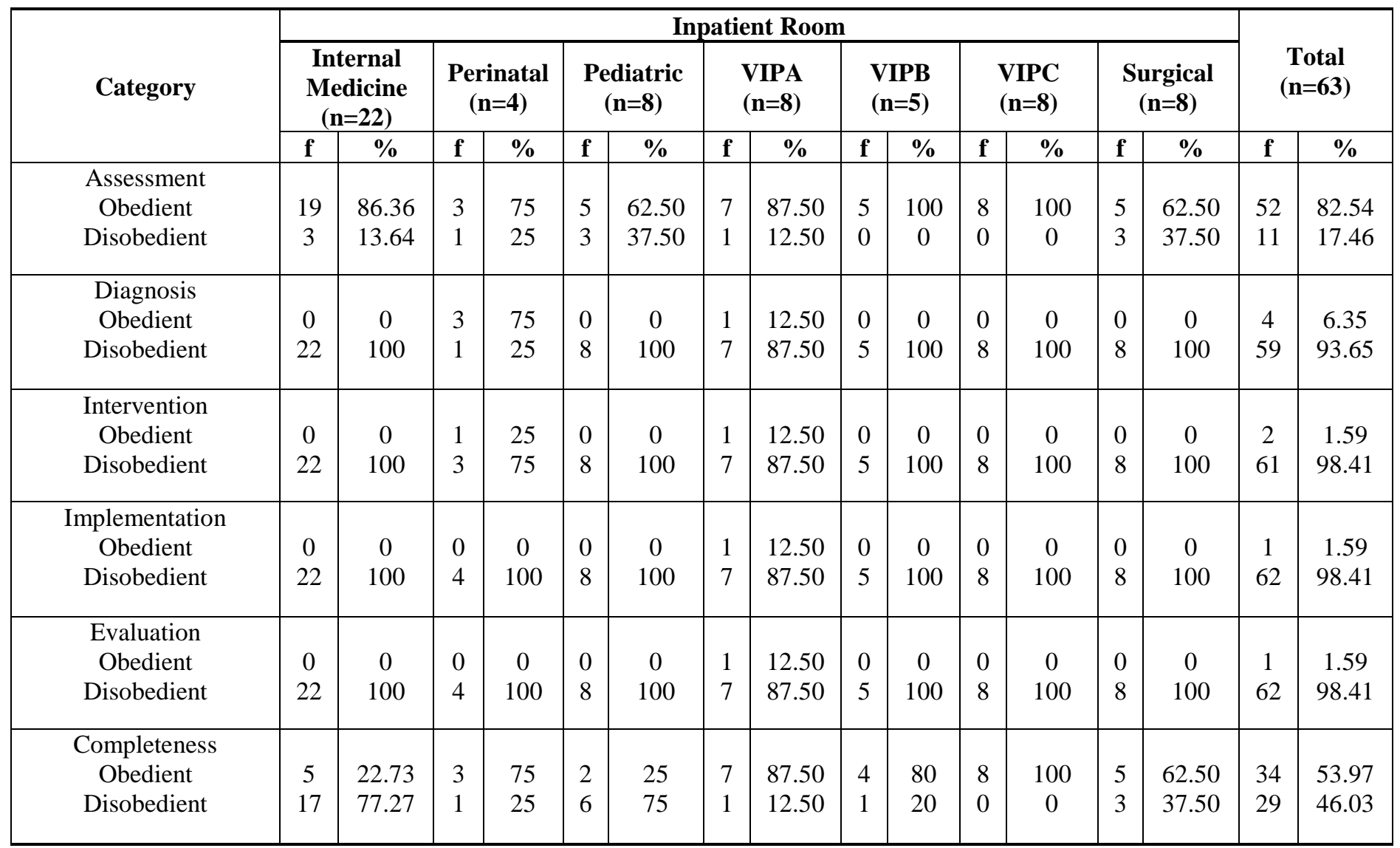

Table 3:- Frequency Distribution in Implementing the Nurses' Obedience Process of Nursing Documentation at the Islamic Hospital Palembang 2018 ( $\mathrm{n}=63)$

Table 3 shows that the highest obedient of nurses in documenting the nursing care process in Islamic Hospital Palembang is the assessment process (82.54\%), the highest obedient of the assessment process at the room level, namely VIP B Room and VIP C Room (100\%).

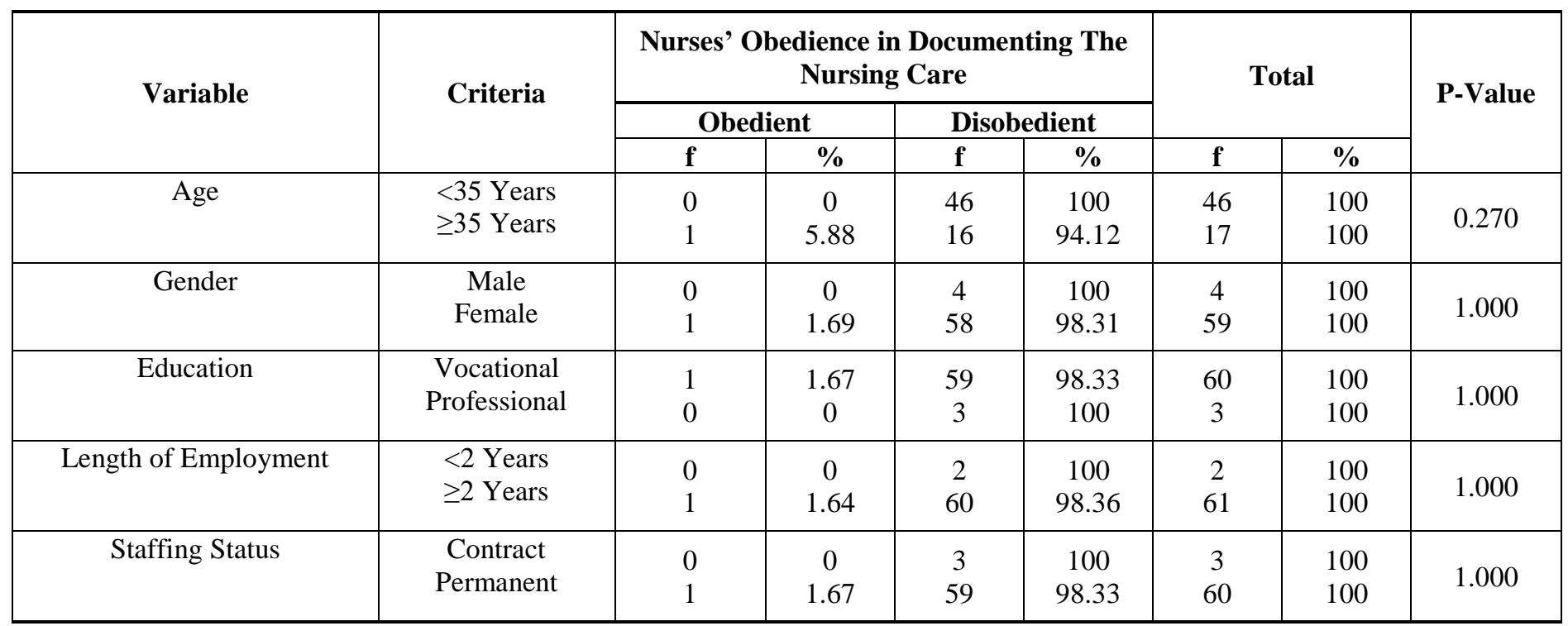

Table 4:- Relationship between Respondents' Characteristics and Nurse Obedience in Documenting The Nursing Care ( $\mathrm{n}=63$ ) 
Table 4 showed that five variables that are related to nursing obedience in documenting the nursing care, of which five variables had no relationship.Variable Age (pvalue $=0.270$ ), while the variables of Gender, Education, Length of Employment, Staffing Status (p-value = 1.000). From these results, it can also be seen that nurses who were obedient in documenting the nursing care were nurses aged $\geq 35$ years of female sex with vocational education, length of employment $\geq 2$ years and status as permanent employees.

Vocational education was nurse education at the level of diploma education, while the professional was nurse education at the professional bachelor level. The status of contract employees was a nurse who worked with a contract system in a certain period that will be extended every time the contract will expire, while permanent employees are nurses who work permanently at the Palembang Islamic Hospital until the retirement age. In this study, researchers divided the age of nurses into two categories to distinguish between early adult age $<35$ years and late adult age $\geq 35$ years.

\section{DISCUSSION}

\section{A. Characteristic of Implementing Nurse in Palembang Islamic Hospital}

Characteristic of a nurse in research it was similar to a number of studies in Islam hospital in Indonesia where the average age of nurses with the highest proportion $<35$ years $(83.33 \%)$, were female $(93.65 \%)$, educated vocational $(92.20 \%)$ [16-18].

Early around age 20 to 40 years is the age of productive nurses [19], This productivity can be measured in the form of the achievement of from the performance of that be performed nurse [20]. This research result indicated that the manager at nurse of Palembang Islamic Hospital is in range productive age, this was proven with the data $73.02 \%$ nurses who be the respondents aged $<35$ years. This age range should be a good factor for nurses to be more productive, but the findings in the field show a different fact where nurses aged $\geq 35$ years were obedient in documenting the nursing care. According to researchers although a nurse is in the age range of productive factors experience but also a factor that affects performance will a nurse and in this research was not the age factor who contributed with our nurses to document the care of nursing in Islamic Hospital Palembang.

Nurses with female sex that most numerous in Inpatient Rooms of Islamic Hospital Palembang (93.65\%), the same thing happens in $\mathrm{H}$ Jakarta Hospital the percentage nurse who are female $(92 \%)$, in PKU Muhammadiyah Yogyakarta Hospital Unit II nurses women $(90.62 \%)$ [12, 21]. According to Megawati [22] nurses with female gender were considered more capable of doing good nursing services when compared to male nurses. Nurse's work includes care and nursing which is usually done by women so that women are more flexible in doing work as nurses [23]. Therefore, in terms of documenting nursing, the Nurses of Islamic Hospital Palembang and other hospitals should be more obedient and more complete. This research proves that nurse who obedient in carrying out to the nursing care documentation are female.

Besides age and gender, documentation also concerning education nurse. Vocational education is the most abundant force in The Inpatient Room of Palembang Islamic Hospital (95.24\%), the same thing is obtained Hayeeduereh [17] in PKU Muhammadiyah Surakarta Hospital nursing staff who have the most vocational education (92.20\%). Highly educated nursing staff will have the knowledge, responsibility and higher capacity and quality [24, 25]. The existence of professional staff in Islamic Hospital Palembang should make the quality of the nursing care documentation produced will also be of higher quality. But the results of the research in Islamic Hospital Palembang showed different facts, the obedient documentation was carried out by nurses with vocational education. According to the researchers' analysis, this happened because professional nurses in Islamic Hospital Palembang still did not optimize their abilities. It can be concluded that the contribution of professionally educated nurses has not been able to improve the obedient of implementing nurses documenting the nursing care in Islamic Hospital Palembang.

In addition to age, gender, and education, documentation is also related to the length of work. The length of time the nurse worked at Palembang Islamic Hospital the proportion of almost $\geq 2$ years $(96.83 \%)$. The results of the study were the characteristics of the length of employment of nurses $\geq 2$ years in several other hospitals, in Zainoel Abidin Hospital Banda Aceh (64.28\%), in the Inpatient Room Sultan Syarif Mohamad Alkadrie Regional Public Hospital (RSUD. Sultan Syarif Mohamad Alkadrie) Pontianak City $(67.85 \%)$ [26, 27]. According to Nursalam [28] the longer someone works, the more experience they have. So it can be concluded that the experience of nurses will influence nurses' obedience in documenting the nursing care. the longer someone works, the more experience they have. So it can be concluded that the experience of nurses will influence nurses' obedience in documenting the nursing care $\geq 2$ years.

Staffing status is also related to nursing obedience in documenting the nursing care. The staffing status of the nursing staff in Islamic Hospital Palembang, the highest proportion of permanent employees $(95.24 \%)$. Research by Shofiana [18] in the Inpatient Room of PKU Muhammadiyah Yogyakarta Hospital also revealed that most nurses were permanent employees (96.66\%). According to Putra, Hamid, \& Ruhana [29] employee status is related to the length of work because this status is achieved based on the results of work experience and performance. It can be concluded that nurses who are permanent employees in Islamic Hospital Palembang are experienced workers. This is evidenced by the results of research that implementing nurses who are obedient in documenting the nursing care in Islamic Hospital Palembang are permanent employees. 
B. Nurse Obedience in Documenting the Nursing Care and Relationship with Nurses' Characteristics in Palembang Islamic Hospital

Obedience of nurses in carrying out the documentation of the nursing care in the Inpatient Room of Palembang Islamic Hospital was very high at $98.41 \%$. The results of several hospitals in Indonesia also revealed nurses' disobedience in documenting the nursing care such as in the Inpatient Room of the Pariaman Regional General Hospital (RSUD. Pariaman) $(60.46 \%)$, in the Inpatient Room of the Ambarawa Regional General Hospital (RSUD. Abarawa) (53.84\%), in the GMIM Pancaran Kasih Hospital Manado (65.78\%) $[4,5,30]$. Examining some of the studies above the disobedience of nurses in the Inpatient Room of the Palembang Islamic Hospital turned out to be higher compared to other types of hospitals in Indonesia. Disobedience in documentation will harm nurses and patients.

The adverse effects of nurse disobedience in documenting the nursing care have the potential to cause malpractice, the absence of legal protection, and the occurrence of repeated nursing actions. Aziz [31] said that the impact of nurse disobedience in documenting the nursing care could harm patients. Triyoga \& Dewi [32] added that the nursing care documentation was used as a tool to identify complaints and diseases experienced by patients and actions to be taken. So that if the nurse does not do good documentation then the possibility of mistakes in taking action will also be greater.

In the implementation of the nursing care, there are six aspects of the process carried out by nurses including the assessment, diagnosis, intervention, implementation, evaluation, and completeness of the nursing care document records. Documentation of the assessment of the nursing care at Palembang Islamic Hospital (82.54\%), the most obedient room are VIP B's room and VIP C's room (100\%), the same thing happened in Inpatient RSI Kendal (80\%), in the Nursing Unit Class III PKU Muhammadiyah Hospital Bantul Yogyakarta (100\%) [33, 34]. Through the above study can be analyzed that the implementation of the assessment documentation of the nursing care inpatient wards Islamic Hospital Palembang has reached the standard of $\geq 80 \%$, but still less when compared with the same type hospital. Based on the analysis of the assessment items found aspects of assessment are not complied by nurses at the Islamic Hospital Palembang on all inpatient unit was recording the data were examined in accordance with the guidelines for the assessment $(11.11 \%)$ and the problem is formulated not by the gap between the health status of the norms and patterns life function $(7.93 \%)$. When the nurse noted the assessment data is not following the guidelines for assessment and are not defined by the gap in health status will affect the continuation of the nursing process.

Inaccurate assessment data will affect the determination of diagnosis, intervention, implementation and evaluation. According to Wijaya, Ahsan, \& Kumboyono [35] appropriate and accurate assessment will affect the accuracy of diagnosis, intervention and implementation. According to House, Goetz, \& Dowell [36] the accuracy and head over of a nurse in conducting the study are also influenced by experience factors. This is what makes the study conducted by nurses in each room different as between Pediatric's Room and VIP C's Room. Thus more and more experience of the nurses in assessing the ability to collect data precision and accuracy of the assessment will also increase. This experience can be obtained nurses attend pieces of training related to the documentation of the nursing care as well as learn and understand the form of the nursing care there.

Implementation of nursing diagnosis documentation Islamic Hospital nurse Palembang largely disobedient (93.65\%), the room was disobedient low is Perinatal Room (25\%). Disobedience of nurses based on the results of research in a hospital that is similar to the hospital in Dr. Moewardi Surakarta (50\%), in Class III Inpatient Unit PKU Muhammadiyah Hospital Bantul Yogyakarta (0\%), Inpatient Hospital Kendal (12.6\%) [33, 34, 37]. Through the above study can be analyzed that the disobedient of nurses in performing nursing diagnosis documentation Islamic Hospital Palembang higher when compared with the same type of hospital. Based on observations on 63 patient statuses, data obtained from almost $100 \%$ of nursing diagnoses did not exist. The nursing diagnosis form is combined with the intervention format using the checklist model, the top of the form is given the title according to the medical diagnosis. This form should be maximized by nurses in the filling because it is easier, directed and do not needs to write over and over.

The nursing diagnosis is an advanced stage of the nursing process. Pereira et al [38] said that nursing diagnoses are an important part of the care stage performed by nurses to solve the problems faced by patients. Esccalanda et al [39] added that determining the right diagnosis will affect the determination of the intervention and can change according to conditions. So the nursing diagnosis is an important stage that can not be ignored by nurses because it involves the process of solving problems and complaints that patients are experiencing, with the nursing diagnosis the nurse will be directed in dealing with the patient's condition. Examining from the above opinion the nurse in the inpatient unit needs to optimize the charging documenting nursing diagnoses.

The nursing process after assessment and diagnosis is intervention. Implementation of the documentation of nursing interventions in the Islamic Hospital Palembang largely of nurse disobedient $(96.83 \%)$, the rooms were disobedient low of Perinatal Room (75\%). Supratman \& Utami [37] research results at Dr. Hospital Moewardi Surakarta $62.50 \%$ of 32 nurses were not obedient. Other studies that revealed nurses' disobedience were also conducted in Class III Inpatient Units PKU Muhammadiyah Hospital Bantul Yogyakarta (0\%), inpatient Hospital Kendal (28\%) [33, 34]. Through the above study can be analyzed that the disobedient of nurses in implementing the intervention documentation of the nursing care at Palembang Islamic Hospital was also very 
high compared to the same type of hospital. Based on observations in several rooms the intervention format was incorporated into the nursing diagnose form sheet in the form of a checklist, but this format had a shortage of nurses' choice in determining intervention, if it was reviewed from intervention items it turned out that all of these items were not done by nurses $(96.82 \%)$, it is necessary to add an empty part or blank format so that the nurse can write other necessary interventions.

Determination of intervention is a follow up of selected nursing diagnoses. According to Palomar, Subirana \& Mila [40] the intervention was made with the aim that the nurse was directed in providing nursing care services. Nursing interventions directed properly will affect the condition of the patient towards good [41]. So when nurses do not do this step the nurse said not to exercise powers he had as nurses in providing nursing care, as well as if the intervention had been made but not implemented by the nurse. Examining from the above opinion than for the next hospital could add an empty column for nurses to write interventions that do not exist yet necessary. With the intervention of the good under the diagnosis and assessment of the results when the nurses can be focused on carrying out the implementation of nursing.

Implementation of nursing carried out as a follow up of nursing interventions. Most of the implementing nurses in the Inpatient Room of the Palembang Islamic Hospital were not obedient in implementing the implementation of the nursing care documentation $(98.41 \%)$, the lowest disobedient room was the AR Fahrudin Room (87.50\%). The results of research on disobedient at Dr. Hospital Moewardi Surakarta (15.60\%), in Class III Inpatient Unit PKU Muhammadiyah Hospital Bantul Yogyakarta (5.30\%), inpatient Hospital Kendal (3\%) [33, 34, 37]. Through the above study can be analyzed that the disobedient of nurses in carrying out the implementation of the nursing care documentation at the Islamic Hospital Palembang higher than the same type of hospital. Based on observations mostly nurses only write routines for services such as operant guard, changing linen, give injections or oral medication, from the aspect of the assessment is not done, namely nurse observe the patient response to nursing actions $(30.15 \%)$, revision of action based on the evaluation results $(63.49 \%)$. So most of the implementing nurses at the Palembang Islamic Hospital implementing the implementation did not refer to nursing interventions.

Implementation of nursing is an action taken by a nurse either independently or collaboration against patients based on diagnosis and intervention are predetermined. According to Li \& Liu [42] implementation of nursing is an activity that must be done by nurses with structured and organized following the intervention. Good knowledge and skills in action played a role important in this stage [43]. So knowledge, teamwork and skills of nurses is needed so it can be run under the implementation of nursing interventions have been. As a form of realization of a good implementation then the nurse needs to optimize the ability to carry out the implementation of appropriate interventions and not write those things which are the main tasks of nurses inpatient care. If the nurse has implemented and writing as should the implementation of nursing evaluation of results of action taken will also show the patient's progress.

The final stage of the nursing process nurses conducted the evaluation of nursing written on the CPPT. Implementation of the documentation of the evaluation of the nursing care at the Islamic Hospital nurse room Palembang largely disobedient $(98.41 \%)$, the lowest in the Room disobedient AR Fahrudin (87.50\%). Research in a hospital similar to the hospital in Dr. Moewardi Surakarta (59.40\%), in Class III Inpatient Unit PKU Muhammadiyah Hospital Bantul Yogyakarta (10.50\%) [34, 37]. Through the above study can be analyzed in comparison with the same type of documentation evaluation of hospital the nursing care at the Islamic Hospital Palembang is still high. Based on observations are largely written evaluation does not refer to an intervention plan $(98.41 \%)$, the evaluation results were not recorded according to the standard and clear $(12.69 \%)$.

The Palembang Islamic Hospital implemented a CPPT/nursing evaluation of the SOAP model. According to Prabowo [1] SOAP is a development note from the documentation model oriented on the problem, and every time an evaluation can occur a revision of the planning section under the actual problem encountered. Budiono \& Pertami [44] said the evaluation aims to end, modify, and continue an intervention and do it after each implementation. Thus the implementing nurse in the inpatient room needs to understand and optimize the documentation of SOAP nursing evaluations according to the SOP and the planned action plan.

The supporting part of the nursing process is the completeness of the nursing care document record. More than half of the implementation nurses were obedient in carrying out documentation of the completeness of the nursing care records at Palembang Islamic Hospital (53.97\%), the highest obedient room namely the $100 \%$ Ibnu Sina Room. The results of the study at the hospital were obedient at the hospital Dr. Moewardi Surakarta (43.80\%), in the Inpatient Room of Pariaman Regional General Hospital (RSUD. Pariaman) (33.80\%), inpatient Hospital RSI Kendal (83.60\%) [30, 33, 37]. Through the above study can be analyzed that the nurses in implementing the document records documenting the completeness of the nursing care at the Islamic Hospital Palembang are still low when compared with same type hospitals that reach the standard of $80 \%$. Observation results of assessment aspects; recording is carried out in accordance with the actions taken $(23.80 \%)$, recording is written clearly, concisely, in standard and correct terms (19.04\%), each action taken by the nurse includes clear name/initial, and date of action (36.50\%), nursing record files are stored in accordance with applicable regulations $(93.65 \%)$. The files that are stored should be based on the order in force at Palembang Islamic Hospital including CPPT (Evaluation), assessment, diagnosis, intervention, and implementation. 
Including the name/initials, date and time of action are essential for nurses. According to Prabowo [1] the nursing care documentation becomes a legal aspect, proof of responsibility and accountability and the legal source of nurse protection in providing services to patients. Hartati [45] adding nurses often forget and seem to ignore to include name/initial, date and time after taking action. According to Bara \& Suryati [46] nurses who do not include name/initial, date and time after taking action will confuse their colleagues. Thus the impact of nurses who do not include names/dates, dates and hours after taking action can potentially occur repeated actions and do not know who has taken action so that it cannot be a material responsibility.

Analysis of the relationship between nurse characteristics and nurse obedience in documenting the nursing care showed no relationship between nurse age ( $p$ value $=0.270)$, gender, education, length of employment, employment status $(p$-value $=1.000)$ at the Palembang Islamic Hospital. Similar results occurred in research Martini [47]; Yanti \& Warsito [48] that there is no relationship between age, length of work, and education. Umtitin [49] research results state that there is a relationship between education level $(p$-value $=0.001)$ while age and employment status have no relationship. There is no correlation between these characteristics indicating that there are other factors that trigger the disobedience of nurses in carrying out documentation. Lack of realization or implementation of the SPO (standard operating procedure) the nursing care documentation at the Palembang Islamic Hospital can also be a trigger for nurse disobedience.

Nurse obedience in documenting the nursing care is inseparable from the SPO made by the hospital. SPO the nursing care is a reference for nurses that contains details of assignments, guidance or direction to carry out documentation of the nursing care $[50,51]$. Therefore SPO is important so that the nursing care documentation can run well. Unfortunately, in the research place, SPO is still in revision and has not been socialized. In addition to SPO should be considered a form of the nursing care facilities are also provided in the room [11, 47], if the form is not available in the room it will hinder the implementation of the nursing process. So far the researchers observed in the form provided in the room is sufficient and experienced no shortage of supplies, the form of the nursing care in the room kept in a storage closet and ordered by the name of medical diagnosis, but it is unfortunate nurses still have not used optimally. This is evidenced by the fact that many forms of intervention diagnosis have not been found inpatient status.

Of all the above findings that the hospital could review the implementation of the nursing care documentation to conduct an internal audit of the nursing documentation. The audit itself can be carried out with the audit team or appoint certain people or directly carried out by the nursing committee. With the nursing audit eating, there will be deficiencies that occur in the field to prevent losses that may be experienced in the future and still maintain the implementation of effective and efficient the nursing care documentation that has an impact on service quality, patient satisfaction and safety $[52,53]$.

In addition to the audit, the head of the room also needs to pay attention to the assignment method is being run. Based on the results of the interview at the initial data collection stage, the method used in the inpatient room was the team method. The team leader certainly must oversee and carry out the implementation of the documentation of the nursing care carried out, because the team leader is the assistant head of the room. So that both the team leader and members must understand and communicate about the job description for the implementation of the nursing care documentation can run well $[54,55]$. But the head of the room as a manager is still needed to supervise and monitor the implementing nurse in the inpatient room.

In the implementation of nursing care with a team method, the team leader as a professional act as a filler in the nursing care assessment, determines the diagnosis, establishes interventions, and divides implementation tasks to the implementing nurse, then evaluates [56]. Based on the results of observations in the field, each nurse fills out the the nursing care documentation form. This certainly contradicts the theory above, so the head of the room as a manager needs to reinforce the role of each team and its functions.

\section{The Strengths and Limitations of the Study}

With this study the Palembang Islamic Hospital can know that there is no relationship between nurse characteristics and nurse obedience in documenting the nursing care, but this study is limited to the relationship between characteristic variables and nurse obedience in documenting the nursing care so that they cannot answer in more detail than the problem that became a phenomenon at the Islamic Hospital of Palembang.

\section{Implications for Nursing Management and Practice}

The results of this study can describe the quality and service of Palembang Islamic Hospital and provide an overview of the obedience of nurses in carrying out documentation of the nursing care. This description can be used as a benchmark for improving the quality of providing nursing care services in inpatient rooms. Disobedience can be improved by providing knowledge through training related to the format of the nursing care used as well as improving tiered education and conducting regular audits.

The disobedience of nurses in documenting the nursing care will result in duplicated actions, the quality of hospital services will be bad and affect the medical record data. Nurse obedience in documenting the nursing care is very beneficial for the hospital, nurses are also patients where all three will receive legal protection, responsibility and accountability, facilitate communication between nurses and the patient's condition can be evaluated appropriately. Another benefit is that it simplifies the service claim process and insurance. 


\section{CONCLUSION}

The study found there was no correlation between nurses' characteristics with nurses in documenting obedience of the nursing care, while nurses in documenting disobedience the nursing care were very high $(98.41 \%)$. The productive age of nurses greatly benefits the hospital because nurses at this age become assets that can be developed better in the future, besides that the increase in nurse education levels can change the mindset of nurses to be better, creative and innovative. Researchers recommend the Palembang Islamic Hospital in order to conduct a review of the format of the nursing care is also SPO the nursing care documentation including SPO implementation, then perform internal audits on a regular basis, provide training or to include nurses in training charging the nursing care documentation used in Islamic Hospital Palembang also need to be done, also optimizing the reward and punishment system for nurses related to the implementation of the nursing care documentation. The next researcher can examine in more detail about the phenomenon that occurred in Palembang Islamic Hospital with a qualitative approach.

\section{REFERENCES}

[1]. T. Prabowo, Nursing Documentation (Dokumentasi Keperawatan). Yogyakarta: Pustaka Baru Press, 2017.

[2]. Potter and Perry, Fundamental of Nursing (Fundamental Keperawatan), 7th ed. Jakarta: Salemba Medika, 2010.

[3]. N. Natasia, A. Loekqijana, and J. Kurniawati, "Factors Affecting Obedience with the Implementation of The nursing care SOPs at Gambiran Hospital ICU-ICCU, Kediri City (Faktor yang Mempengaruhi Kepatuhan Pelaksanaan SOP Asuhan Keperawatan di ICU-ICCU RSUD Gambiran Kota Kediri)," J. Kedokteran. Brawijaya, vol. 28, no. 1, pp. 21-25, 2014.

[4]. I. D. Nurseto, N. Sukesi, and Wulandari, "Effect of Nurse Satisfaction on the Complete Documentation of The nursing care in the Inpatient Room of Ambarawa Hospital (Pengaruh Kepuasan Perawat Terhadap Kelengkapan Dokumentasi Asuhan Keperawatan di Ruang Rawat Inap RSUD Ambarawa)," pp. 1-10, 2014.

[5]. R. A. Rapar, R. Kundre, and V. Kallo, "Relationship between Nurse's Job Satisfaction with the Implementation of Documentation of Nursing at GMIM Hospital Pancaran Kasih Manado (Hubungan Kepuasaan Kerja Perawat dengan Pelaksanaan Pendokumentasian Keperawatan di Rumah Sakit GMIM Pancaran Kasih Manado)," e-Jurnal Keperawatan (e-Kp), vol. 6, no. 1, 2018.

[6]. D. R. Hidayat, Human Behavior Science, Introduction to Psychology for Medical Health Workers (Ilmu Perilaku Manusia, Pengantar Psikologi untuk Tenaga Kesehatan Medis). Jakarta: Trans Info Media, 2009.

[7]. E. D. Purwanti, "Complete Documentation of The nursing care and Its Characteristics in Adult NonMidwifery Patients in Jakarta Hajj Hospital
(Kelengkapan Dokumentasi Asuhan Keperawatan dan Karakteristiknya Pada Pasien Rawat Inap Dewasa Non Kebidanan Di Rumah Sakit Haji Jakarta)," Universitas Indonesia, Jakarta, Indonesia, 2012.

[8]. M. Nurman, "actors Associated With Documentation of Nursing in the Inpatient Room of the Bangkinang General Hospital (Faktor - Faktor yang Berhubungan Dengan Pendokumentasian Keperawatan di Ruang Rawat Inap RSUD Bangkinang)," vol. 19, pp. 1-13, 2013.

[9]. I. Utami, "Not obedience (Ketidak Patuhan)," 18 Januari 2017, 2017. [Online]. Available: https://www.scribd.com/document/336893143/ketidak patuhan. [Accessed: 26-Jun-2017].

[10]. L. Meivinia, "Disobedience (Ketidakpatuhan)," 2017. [Online]. https://www.coursehero.com/file/p23gmup/80DEFINISI-Ketidakpatuhan-Tindakan-penghilanganatau-tindakan-kejahatan-oleh/.

[11]. S. Aswar, S. Hamsinah, and A. Kadir, "Factors Affecting the Effectiveness of the Implementation of Documentation of The nursing care in the Inpatient Installation of Surgery at the General Hospital of Andi Makkasau Parepare (Faktor yang Mempengaruhi Efektifitas Pelaksanaan Pendokumentasian Asuhan Keperawatan di Instalasi Rawat Inap Bedah Rumah Sakit Umum Daerah Andi Makkasau Parepare)," J. Ilm. Kesehat. Diagnosis, vol. 5, no. 4, pp. 460-466, 2014.

[12]. D. Nuryani and R. T. S. Hariyati, "Knowledge and Attitudes of Nurses on the Complete Documentation of The nursing care at Jakarta $\mathrm{H}$ Hospital (Pengetahuan dan Sikap Perawat Terhadap Kelengkapan Pendokumentasian Asuhan Keperawatan di Rumah Sakit H Jakarta),” pp. 1-9, 2014.

[13]. A. Pribadi, "Analysis of the Influence of Knowledge Factors, Motivation, and Nurse Perception About the Supervision of the Head of the Room on the Implementation of Documentation of The nursing care in the Inpatient Room of the General Hospital of the Kelet Jepara, Central Java Province (Analisis Pengaruh Faktor Pengetahuan, Motivasi, dan Persepsi Perawat Tentang Supervisi Kepala Ruang Terhadap Pelaksanaan Dokumentasi Asuhan Keperawatan di Ruang Rawat Inap RSUD Kelet Jepara Provinsi Jawa Tengah)," Universitas Diponegoro, Semarang, Indonesia, 2009.

[14]. J. Gibson, J. M. Ivancevich, J. H. Donnelly, and R. Konopaske, Organizations: Behavior, Structure, Processes, 14th ed. Boston: McGraw-Hill, 2012.

[15]. R. Depkes, An Instrument for Evaluating the Application of The nursing care Standards at Hospitals (Instumen Evaluasi Penerapan Standar Asuhan Keperawatan di Rumah Sakit. Indonesia), 2015.

[16]. M. Ulfa and T. Sarzuli, "The Effect of Internal and External Factors on Nurses' Obedience in Implementing Standard Catheter Installation Procedures at PKU Muhammadiyah Yogyakarta Unit II Hospital (Pengaruh Faktor Internal dan Eksternal Terhadap Kepatuhan Perawat Dalam Melaksanakan 
Standar Prosedur Operasional Pemasangan Kateter di Rumah Sakit PKU Muhammadiyah Yogyakarta Unit II)," J. Medicoeticolegal dan Manaj. Rumah Sakit, vol. 5, no. 1, pp. 49-55, 2016.

[17]. W. Hayeeduereh, "The Description of The Nurses' Knowledge About The Quality Service At PKU Muhammadiyah Hospital Surakarta,” 2016.

[18]. A. M. Shofiana, "Relationship between Nurse Perception About the Benefits of Discharge Planning and the Implementation of Discharge Planning in the Inpatient Room of PKU Muhammadiyah Yogyakarta Hospital (Hubungan Persepsi Perawat Tentang Manfaat Discharge Planning dengan Pelaksanaan Discharge Planning di Ruang Rawat Inap Rumah Sakit PKU Muhammadiyah Yogyakarta)," 2014.

[19]. S. Aprilyanti, "Effect of Age and Work Period on Work Productivity (Pengaruh Usia dan Masa Kerja Terhadap Produktivitas Kerja)," J. Sist. dan Manaj. Ind., vol. 1, no. 2, pp. 68-72, 2017.

[20]. S. P. Robbins and T. A. Judge, Organizational Behavior, 15th ed. United States of America: Prentice Hall, 2012.

[21]. F. S. Fatimah, "verview of the Application of the Correct Principle of Giving Medicine in PKU Muhammadiyah Yogyakarta Unit II Hospital (Gambaran Penerapan Prinsip Benar Pemberian Obat di Rumah Sakit PKU Muhammadiyah Yogyakarta Unit II)," J. Ners dan Kebidanan Indones., vol. 4, no. 2, p. 79, 2016.

[22]. Megawati, "Analysis of the Effect of Characteristics of Individuals on Nurse's Performance at Dr. Pirngadi Medan in 2017 (Analisis Pengaruh Karakteristik Individu Terhadap Kinerja Perawat di Rumah Sakit Dr. Pirngadi Medan Tahun 2017)," JUMANTIK (Jurnal Ilm. Penelit. Kesehatan), vol. 2, no. 1, pp. 113, 2017.

[23]. N. R. Rusnawati, "Gender Relations in Nursing Tasks at Puri Husada Hospital Sleman Yogyakarta (Relasi Gender dalam Tugas-Tugas Keperawatan di Rumah Sakit Puri Husada Sleman Yogyakarta),' Universitas Negeri Yogyakarta, Yogyakarta, 2012.

[24]. E. Manuho, H. Warouw, and R. Hamel, "Relationship between Workload and Nurse Performance in Giving The nursing care in C1 Inpatient Installation RSUP Prof. DR.R.D. Kandou Manado (Hubungan Beban Kerja dengan Kinerja Perawat dalam Pemberian Asuhan Keperawatan di Instalasi Rawat Inap C1 RSUP Prof. DR.R.D. Kandou Manado)," ejournal Keperawatan, vol. 3, no. 2, pp. 1-8, 2015.

[25]. T. R. P. Lestari, "Nursing Education: An Effort to Produce Quality Nurses (Pendidikan Keperawatan: Upaya Menghasilkan Tenaga Perawat Berkualitas)," Aspirasi, vol. 5, no. 1, pp. 1-10, 2014.

[26]. C. Husna and I. Fitriani, "Executing Nurses Competence in Caring for HIV / AIDS Patients (Kompetensi Perawat Pelaksana Dalam Merawat Pasien HIV/AIDS)," Idea Nurs. J., vol. VII, no. 1, pp. 70-78, 2016.

[27]. V. Christy, "Relationship between Characteristics of Nurses and Application of Therapeutic Communication to Patients in Inpatient Rooms at the
Sultan Syarifmohamad Alkadrie Regional Hospital in Pontianak (Hubungan Karakteristik Perawat dengan Penerapan Komunikasi Terapeutik Pada Pasien Di Ruang Rawat Inap Rsud Sultan Syarifmohamad Alkadrie Kota Pontianak)," 2015.

[28]. Nursalam, Education in Nursing (Pendidikan Dalam Keperawatan). Jakarta: Salemba Medika, 2009.

[29]. B. P. Putra, D. Hamid, and I. Ruhana, "Analysis of Contract Employee Work Comparison with Permanent Employees (Analisis Perbandingan Prestasi Kerja Karyawan Kontrak Dengan Karyawan Tetap)," J. Adm. Bisnis, vol. 26, no. 1, pp. 1-6, 2015.

[30]. R. Sandra, R. Sabri, and D. Wanda, "Analysis of the Relationship between Implementing Nurses' Motivation and the Implementation of Documentation of The nursing care in the Inpatient Room of the Pariaman General Hospital (Analisis Hubungan Motivasi Perawat Pelaksana dengan Pelaksanaan Pendokumentasian Asuhan Keperawatan di Ruang Rawat Inap RSUD Pariaman)," 2012.

[31]. A. Aziz, "Criminology Review Regarding Medical Malpractice Performed by Nurses (Tinjauan Kriminologi Mengenai Malpraktik Medik yang Dilakukan Oleh Perawat)," J. Ilmu Huk. Leg. Opin., vol. 2, no. 2, pp. 1-10, 2014.

[32]. A. Triyoga and P. A. K. Dewi, "Implementation of Nursing Documentation in Inpatient Installation of Kediri Baptist Hospital (Pelaksanaan Dokumentasi Keperawatan di Instalasi Rawat Inap Rumah Sakit Baptis Kediri)," J. Penelit. Keperawatan, vol. 1, no. 2, pp. 155-164, 2015.

[33]. S. Sugiyati, "Relationship between Nurse Knowledge in Nursing Documentation and Implementation in Inpatient at Kendal Islamic Hospital (Hubungan Pengetahuan Perawat Dalam Dokumentasi Keperawatan dengan Pelaksanaannya di Rawat Inap RSI Kendal)," in Prosiding Konferensi Nasional II PPNI Jawa Tengah, 2014, pp. 298-307.

[34]. C. E. Lestari and Rosyidah, "Analysis of Nurse Obedience in The nursing care Standards in Class III Inpatient Units PKU Muhammadiyah Hospital Bantul Yogyakarta in 2010 (Analisis Kepatuhan Perawat Pada Standar Asuhan Keperawatan Di Unit Rawat Inap Kelas III RSU PKU Muhammadiyah Bantul Yogyakarta Tahun 2010)," J. Kesehat. Masy. (Journal Public Heal. Univ. Ahmad Dahlan, vol. 5, no. 1, pp. 45-49, 2011.

[35]. I. M. S. Wijaya, Ahsan, and Kumboyono, "Nurse Experience Conducts Emergency Nursing Assessment (Pengalaman Perawat Melaksanakan Pengkajian Keperawatan Kegawatdaruratan)," pp. 1-6, 2014.

[36]. S. K. House, M. A. Goetz, and S. Dowell, "Utilization of Nursing Home Residents for Development of Assessment Skills," Teach. Learn. Nurs., vol. 10, no. 3, pp. 128-131, 2015.

[37]. Supratman and Y. W. Utami, "Documentation of The nursing care Viewed from Nurse's Workload (Pendokumentasian Asuhan Keperawatan Ditinjau Dari Beban Kerja Perawat)," Ilmu Keperawatan, vol. 2, no. 1, pp. 7-12, 2009. 
[38]. F. Pereira et al., "Nursing Diagnoses of the Homeless Population in Light of Self-care Theory," Arch. Psychiatr. Nurs., no. December, 2017.

[39]. P. Escalada-Hernandez et al., "A Retrospective Study of Nursing Diagnoses, Outcomes, and Interventions for Patients with Mental Disorders," 2014.

[40]. X. Palomar-Aumatella, M. Subirana-Casacubertaa, and R. Mila-Villarroel, "Critical care nursing interventions and the time required for their," Intensive Crit. Care Nurs., pp. 1-7, 2017.

[41]. S. Aranda, "Designing Nursing Interventions," Collegian, vol. 15, no. 1, pp. 19-25, 2008.

[42]. M. Li and H. Liu, "Implementation of A Clinical Nursing Pathway for Percutaneous Coronary Intervention: A Prospective Study," Geriatr. Nurs. (Minneap)., pp. 1-4, 2018.

[43]. D. N. Siahaan and M. Tarigan, "Nurse Performance in Giving The nursing care at TK II Putri Hijau Hospital Medan (Kinerja Perawat dalam Pemberian Asuhan Keperawatan di RS TK II Putri Hijau Medan)," J. Keperawatan Holistik, vol. 1, no. 2, pp. 29-34, 2012.

[44]. Budiono and S. B. Pertami, Basic Concepts of Nursing (Konsep Dasar Keperawatan). Jakarta: Bumi Medika, 2017.

[45]. S. Hartati, "The Quality of Documentation of The nursing care in the Inpatient Room of PKU Muhammadiyah Hospital in Yogyakarta (Kualitas Dokumentasi Asuhan Keperawatan di Ruang Rawat Inap RS PKU Muhammadiyah Yogyakarta),” 2010.

[46]. Bara and Suryati, "Relationship between Nurses' Motivation and the Implementation of Documentation of The nursing care in the Inpatient Room at Pasar Rebo Hospital (Hubungan Motivasi Perawat dengan Pelaksanaan Pendokumentasian Asuhan Keperawatan di Ruang Rawat Inap RSUD Pasar Rebo)," J. Heal. Qual., vol. 5, no. 1, pp. 1-66, 2014.

[47]. Martini, "Relationship between Nurse Characteristics, Attitudes, Workloads, Availability of Facilities and Documentation of The nursing care in Inpatient Care at the BPRSUD Salatiga City (Hubungan Karakteristik Perawat, Sikap, Beban Kerja, Ketersediaan Fasilitas dengan Pendokumentasian Asuhan Keperawatan di Rawat Inap BPRSUD Kota Salatiga)," Universitas Diponegoro Semarang, 2007.

[48]. R. I. Yanti and B. E. Warsito, "Relationship between Nurse Characteristics, Motivation, and Supervision with the Quality of Nursing Care Process Documentation (Hubungan Karakteristik Perawat, Motivasi, dan Supervisi dengan Kualitas Dokumentasi Proses Asuhan Keperawatan)," J. Manag. Keperawatan, vol. 1, no. 2, pp. 107-114, 2013.

[49]. Umtitin, 'Relationship between Nurses' Characteristics and Obedience Carrying Out The nursing care Documentation at the Regional Mental Hospital Dr. Amino Gondohutomo Semarang (Hubungan Karakteristik Perawat Dengan Kepatuhan Melaksanakan Dokumentasi Asuhan Keperawatan di Rumah Sakit Jiwa Daerah Dr. Amino Gondohutomo Semarang)," Muhammadiyah University Semarang, 2007.
[50]. C. M. Barbosa, M. F. Z. Mauro, S. A. B. Cristóvão, and J. A. Mangione, "The Importance of Standard Operating Procedures (SOPs) for Clinical Research Centers.," Rev. Assoc. Med. Bras., vol. 57, no. 2, pp. 134-135, 2011.

[51]. K. Sunde, "SOPs and The Right Hospitals to Improve Outcome After Cardiac Arrest," Best Pract. Res. Clin. Anaesthesiol., vol. 27, no. 3, pp. 373-381, 2013.

[52]. G. Priyadi, Quality System Audit Guide (Panduan Audit Sistem Mutu). Jakarta: Bumi Aksara, 2012.

[53]. V. Wardhani, Patient Safety Management (Manajemen Keselamatan Pasien). Malang: UB Press, 2017.

[54]. M. Balki, D. Hoppe, D. Monks, M. E. Cooke, L. Sharples, and R. Windrim, "Multidisciplinary Delphi Development of a Scale to Evaluate Team Function in Obstetric Emergencies: The PETRA Scale," JOGC JUIN, vol. 39, no. 6, pp. 434-442.e2, 2017.

[55]. Y. R. Lapeña-Moñux, L. Cibanal-Juan, M. L. MaciáSoler, M. I. Orts-Cortés, and A. Pedraz-Marcos, "Interpersonal Relations and Nurses' Job Satisfaction Through Knowledge and Usage of Relational Skills," Appl. Nurs. Res., vol. 28, no. 4, pp. 257-261, 2015.

[56]. M. H. Bakri, Nursing Management, Concepts and Applications in Professional Nursing Practices (Manajemen Keperawatan, Konsep dan Aplikasi dalam Praktik Keperawatan Profesional). Yogyakarta: Pustaka Baru Press, 2017. 